\title{
Pengering Tenaga Surya dengan Sistem Bekap Tenaga Biomassa untuk Pengeringan Hasil Pertanian
}

\author{
Solar dryer with a biomass burner back-up system for drying of agricultural products
}

\author{
Elieser Tarigan ${ }^{1 *}$
}

${ }^{1}$ Teknik Elektro, Fakultas Teknik, dan Pusat Studi Lingkungan dan Energi Terbarukan (PuSLET), Universitas Surabaya, J. Raya Kalirungkut, Surbaya, 60292, Indonesia

*Email: elieser@staff.ubaya.ac.id

Diterima: 16 Desember 2019; Disetujui: 30 Agustus 2020

\begin{abstract}
ABSTRAK
Tulisan ini memaparkan sistem pengering tenaga surya yang dibekap dengan panas dari pembakaran biomassa. Alat ini digunakan untuk pengeringan hasil pertanian. Metode penelitian mencakup studi literatur tentang karakteristik pengeringan produk pertanian, membangun alat pengering, dan pengujian kinerja pengering. Dari hasil experimen diketahui bahwa pengering tenaga surya tersebut sangat efektif untuk mengeringkan berbagai jenis hasil pertanian seperti cabe rawit, kemiri, kacang kedelai, kacang hijau, dan kopi dimana temperatur pengeringan berkisar $40-65^{\circ} \mathrm{C}$. Pengering tenaga surya diharapkan dapat dikembangkan dan dimanfaatkan untuk meningkatkan kuantitas dan kualitas produk pertanian bagi para petani.
\end{abstract}

Kata kunci: biomassa; hasil pertanian; pengering; tenaga surya

\section{ABSTRACT}

This paper describes a solar dryer with a biomass burner back-up system. The dryer is intended for the drying of agricultural products. The dryer was build and the performance was evaluated. The research method involved the literature reviews, desain a solar dryer, constructing, and performance testing for the dryer. It was found that the dryer is suitable for drying various agricultural products such as chili, candlenuts, soybeans, green beans, and coffee beans where the need for drying temperature is around $40-65^{\circ} \mathrm{C}$. It is expected that the dryer can be further developed and used to increase quality and the quantity of the agricultural products by the farmers.

Keywords: biomass; agricultural products; solar drying; solar energy

\section{PENDAHULUAN}

Proses pengeringan merupakan salah satu proses pasca panen untuk berbagai produk hasil pertanian (Kumar, Sansaniwal, \& Khatak, 2016). Penjemuran langsung di bawah sinar matahari secara terbuka merupakan metode pengeringan tradisonal yang paling sederhana dan masih banyak dilakukan oleh petani di Indonesia. Banyak kendala yang dialami dengan metode ini seperti tidak menentunya cuaca, kontaminasi produk, masalah higienis, dan berbagai hal yang pada akhirnya berpengaruh pada kualitas dan kuantitas produk pertanian.

Dilain pihak pemakaian mesin pengering modern menambah biaya produksi dan tidak terjangkau oleh petani, disamping dampak negatif yang terjadi sebagai akibat dari pembakaran sumber energi fosil dalam mesin (El-Sebaii \& Shalaby, 2012). Solusi yang diusulkan dalam tulisan ini adalah pemanfaatan pengering tenaga surya dengan sistem bekap, terinspirasi dari hasil penelitian sebelumnya yang pernah dilaporkan (Bahnasawy \& Shenana, 2004; Morad, El-Shazly, Wasfy, \& El-Maghawry, 2017; Sharma, Sharma, \& Garg, 1991; E. Tarigan \& Tekasakul, 2007; Elieser Tarigan, 2018). Tenaga surya merupakan sumber energi yang bersih, ketersediaanya melimpah terutama di daerah sekitar khatulistiwa termasuk wilayah Indonesia, serta dapat diperoleh dengan bebas. Untuk mengantisipasi cuaca yang tidak menentu, sistim pengering tenaga surya dibekap dengan panas yang diperoleh dari pembakaran biomassa.
Pengering tenaga surya (solar dryer) merujuk pada suatu alat pengering yang dirancang dengan memanfaatkan energi surya sebagai sumber energi. (Pengertian solar dryer berbeda dengan sun dryer, dimana sun dryer merupakan penjemuran langsung di bawah sinar matahari di ruang terbuka). Terdapat berbagai jenis dan tipe pengering tenaga surya yang digolongkan masing masing menurut cara pemanafatan radiasi surya, alat bantu, dan jenis produk yang dikeringkan (Fudholi et al., 2018; Kabeel \& Abdelgaied, 2016; Kumar et al., 2016; Wu et al., 2017).

Berdasarkan bagaimana bahan yang dikeringkan mendapatkan panas dari radiasi surya, pengering tenaga surya dibedakan menjadi (1) pengering tipe langsung; (2) pengering tipe tidak langsung; dan (3) pengering tipe gabungan (hybrid dryer) (Kabeel \& Abdelgaied, 2016). Pada pengering tipe langsung, radiasi matahari langsung mengenai bahan yang yang dikeringkan. Sementara pada pengering tipe tidak langsung, radiasi surya dimanfaatkan untuk memanaskan udara, dan selanjutnya udara yang panas dilewatkan pada bahan yang dikeringkan. Pada pengering tipe gabungan, radiasi surya dimanfaatkan baik langsung pada bahan yang dikeringkan maupun untuk memanaskan udara untuk mengeringkan.

Berdasarkan pemanfatan alat bantu, pengering tenaga surya dibedakan menjadi: (1) pengering tipe aktif, dan (2) pengering tipe passif. Pengering tipe aktif memanfaatkan alat bantu atau alat mekanik lain seperi kipas atau blower, sementara pengering tipe pasif tidak memanfaatkan alat 
bantu lain sehingga untuk sirkulasi udara menggunakan sirkulasi konveksi bebas alami.

Menurut jenis produk yang dikeringkan pengering tenaga surya dibedakan menjadi: (1) pengerering tipe produk tunggal (single products dryer) dan (2) pengering multi produk (multi product dryer).

Para petani seringkali menghadapi persolan terkait dengan pengeringan produk mereka, dan dari hasil percobaan didapati bahwa pengering tenaga surya dapat dan menjadi solusi. Permasalahan bahwa tenaga surya seringkali sangat bergantung pada cuaca, dapat diatasi dengan melengkapi pengering tersbut dengan sistem bekap biomassa. Dalam percobaan ini biomassa yang dipakai adalah kayu bakar, namun pada prakteknya dapat juga dari berbagai bentuk bahan biomassa sampingan yang tidak terpakai misalnya, sekam, tempurung kelapa, dan lain-lain.

Bentuk dan desain pengering surya sangat bervariasi dan dapat disesuaikan dengan kebutuhan menurut lokasi. Desain dan bahan konstruksi sebuah pengering tenaga surya pada umumnya sangat sederhana, sehingga dapat dibangun sendiri oleh para petani.

Persoalan yang mungkin muncul adalah bagaiman mengenalkan sistem ini kepada para petani dan juga mengubah kebiasaan tradisional dengan penjemuran menjadi memakai alat pengering surya. Disamping itu mungkin juga jadi hambatan untuk investasi awal pembuatan pengering. Dalam hal ini perlu dukungan dan perhatian dari berbagai pihak terutama pemerintah dan pengusaha untuk melakukan stimulasi.

Pemanfaatan pengering tenaga surya (dengan bekap tenaga biomass) dapat menjadi salah satu sarana dalam upaya peningkatan produktifitas petani sekaligus pemanfaatan energi terbarukan yang ramah lingkungan.

Pada tulisan ini, dipaparkan sebuah model pengering type gabungan (hybrid) yang telah dibangun dan diuji. Tipe yang tetapkan adalah pengering tipe pasif yang memanfatkan sukurlasi konveksi bebas. Pengering tersebut didesain untuk multiproduk dan telah dievaluasi untuk pengeringan beberapa jenis hasil pertanian seperti cabe rawit, kemiri, kacang kedelai, dan kopi. Desain dan fitur-fitur pengering, serta hasil evaluasi pengeringan dipaparkan pada bagian hasil dan pembahasan.

\section{METODOLOGI PENELITIAN}

Metode penelitian pada studi ini mencakup studi literatur tentang karakteristik pengeringan produk pertanian, mendesain alat pengering, membangun alat pengering, dan pengujian kinerja pengering.

Desain sebuah pengering haruslah mempertimbangkan berbagai aspek, termasuk karakteristik pengeringan produk yang akan dikeringkan terutama temperatur yang sesuai, serta hal-hal non teknis seperti: kemudahan mendapatkan bahan bangunan pengering, pertimbangan ekonomis dan lain-lain. Secara garis besar alur penelitian dilakukan sebagaimana ditunjukkan pada bagan alur pada Gambar 1.

Evaluasi atau pengujian pengering yang dibangun pertama-tama dilakukan dengan tanpa beban untuk mengetahui temperatur kerja. Pengujian kemudian dilakukan dengan beban (bahan yang dikeringkan) untuk beberapa jenis produk yang berbeda seperti disebutkan sebelumnya.

Pada evaluasi pengering tanpa beban atau dalam keadaan kosong, parameter evaluasi utama adalah mengukur temperatur. Evaluasi juga dilakukan untuk masing-masing sumber energi (1) surya; (2) biomassa; (3) gabungan surya dan biomassa.

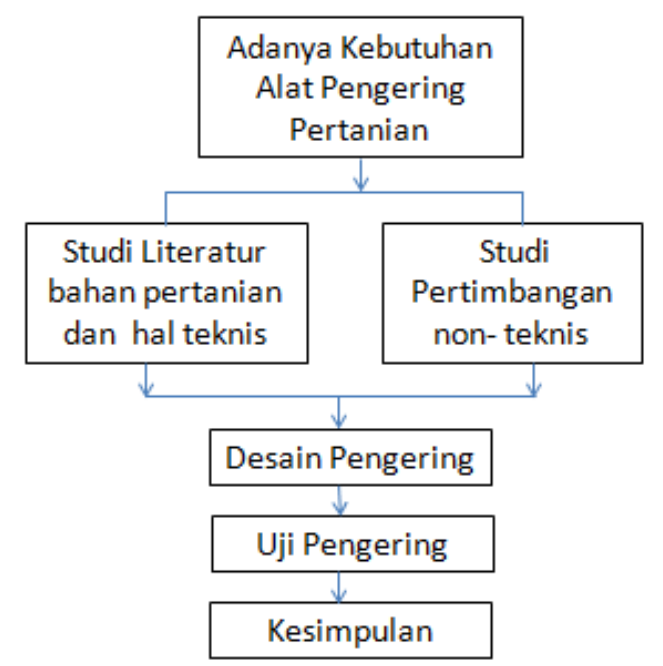

Gambar 1. Diagram alur penelitian

\section{HASIL DAN PEMBAHASAN}

Literatur menunjukkan bahwa temperatur pengeringan yang sesuai untuk sebahagian besar produk pertanian adalah antara 40 - $65{ }^{\circ} \mathrm{C}$ (El-Sebaii \& Shalaby, 2012; Kumar et al., 2016; Simate, 2003; Yassen \& Al-Kayiem, 2016). Khusus untuk karakteristik produk cabe dilaporkan oleh Rabha dkk., (Rabha, Muthukumar, \& Somayaji, 2017). $\mathrm{Hal}$ tersebut dapat dipakai sebagai indikasi awal bahwa pengering tersebut dapat digunakan untuk produk hasil pertanian.

Dengan mempertimbangkan kemudahan mendapatkan bahan bangunan pengering, kemudahan untuk pembangunannya, kemudahan untuk operasi, serta pertimbangan ekonomis maka type pengering yang diusulkan dalam penelitian ini adalah pengering tenaga surya dengan sistem backup biomassa. Pengering terdiri dari tiga bagian utama: (1) kotak dan rak dimana produk ditempatkan, (2) kolektor surya (solar kolektor) dan (3) sitem bekap. Detail bagian-bagian sistem pengering diperlihatkan pada Gambar 2. Pengering tersebut merupakan tipe gabungan dimana radiasi matahari dimanfaatkan baik langsung maupun tidak langsung untuk mengeringkan produk.

Radiasi langsung masuk lewat atap rak yang terbuat dari kaca transparan. Sementara radiasi tidak langsung untuk mendapakan udara panas dipakai kolektor surya yang terbuat dari seng yang dicat hitam. Kotak dan rak dimana produk ditempatkan dilingkupi dengan dinding yang terdiri dari didning luar, spasi kosong, dan dinding dalam. Didalam dinding luar ditempatkan lapisan. Radiasi langsung masuk lewat atap rak yang terbuat dari kaca transparan. Sementara radiasi tidak langsung untuk mendapakan udara panas dipakai kolektor surya yang terbuat dari seng yang dicat hitam. Kotak dan rak dimana produk ditempatkan dilingkupi dengan dinding yang terdiri dari dinding luar, spasi kosong, dan dinding dalam. Didalam dinding luar ditempatkan lapisan

Sistem bekap terdiri dari tungku pembakaran biomassa dan media penyimpan panas berupa susunan batu bata yang diletakkan diatas dan disamping tungku. Sistem bekap terdiri dari tungku pembakaran biomassa dan media penyimpan panas berupa susunan batu bata yang diletakkan diatas dan disamping tungku. 


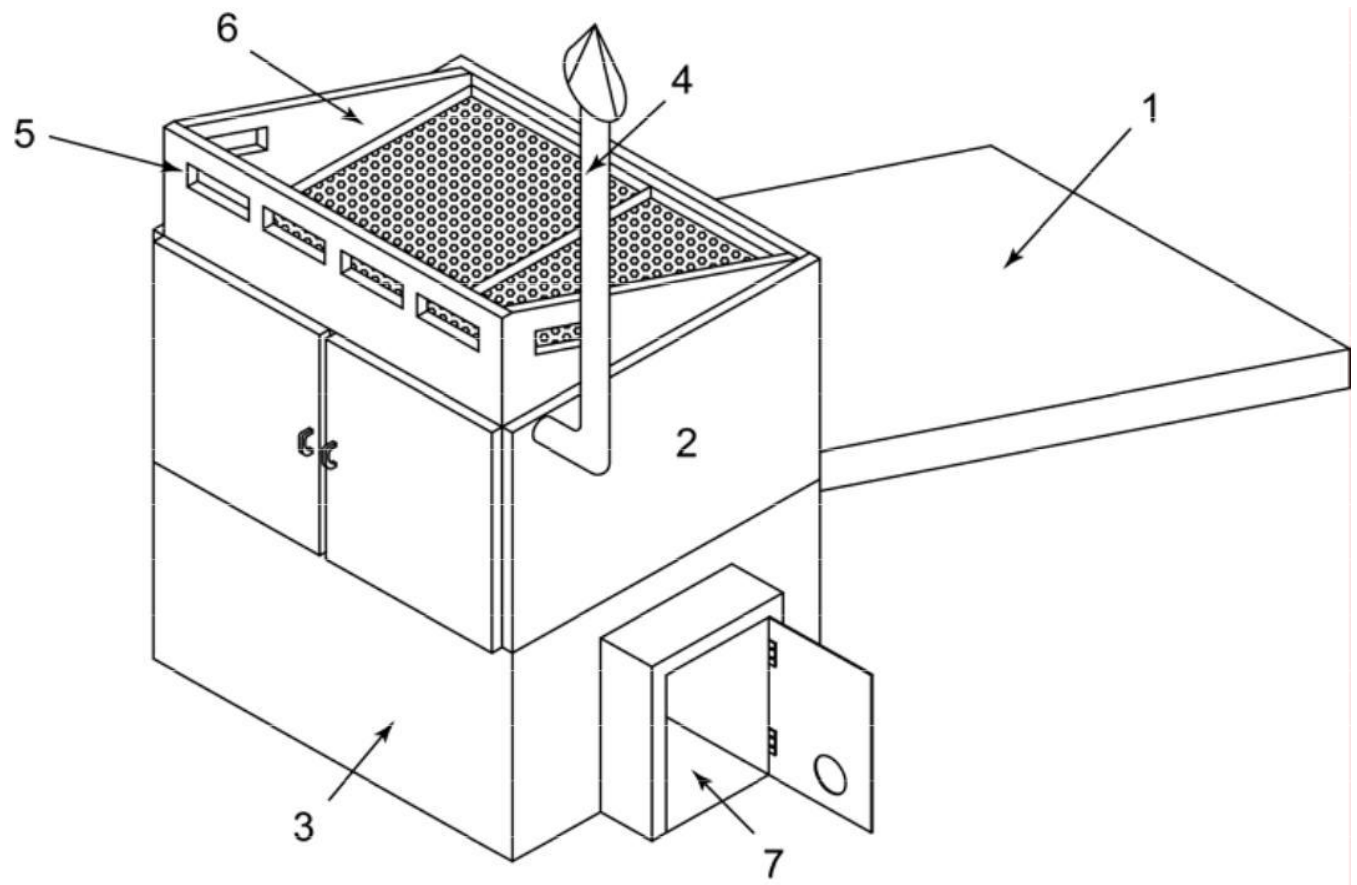

Gambar 2. Pengering tenaga surya dengan sistem bekap biomass. Bagian-baigan sistem: 1. kolektor surya, 2. kotak dan rak, 3. media penyimpan panas, 4. cerobong asap, 5. ventilasi, 6. atap transparan, 7. tungku pembakaran biomassa

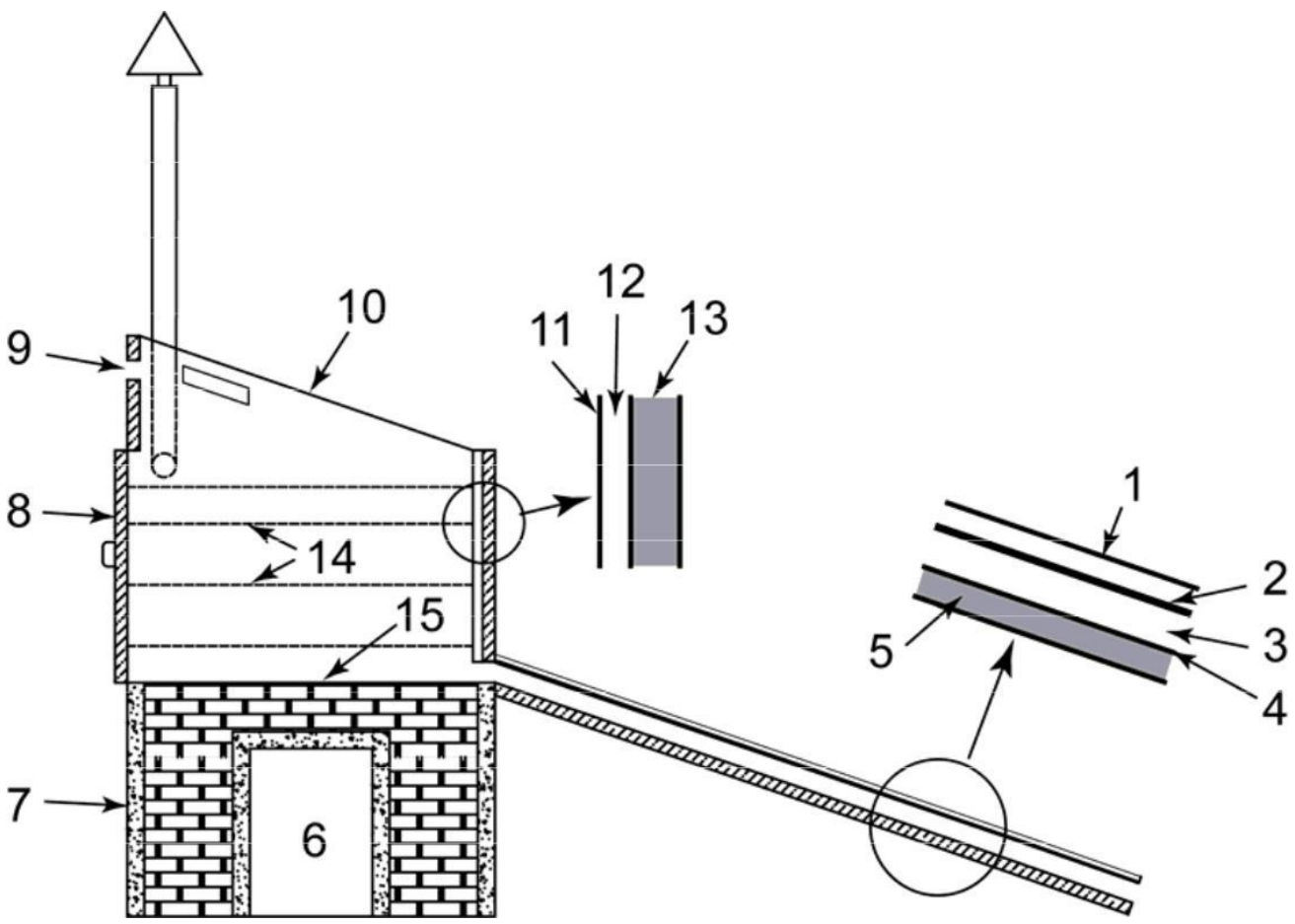

Gambar 3. Penampang melintang tampak samping pengering: 1. penutup transparan (kaca); 2. lempeng penyerap panas; 3. spasi ruang masuk udara, 4. lapisan bawah spasi ruang gerak udara; 5 . insulasi; 6 . tungku pembakaran biomassa; 7. media penyimpa panas; 8. pintu rak pengering; 9. ventilasi; 10. atap transparan; 11. dinding internal rak; 12. spasi kosong tempat aliran asap; 13. dinding luar rak dengan insulasi, 14. rak/tray pengering; 15. plat bawah rak/tray 


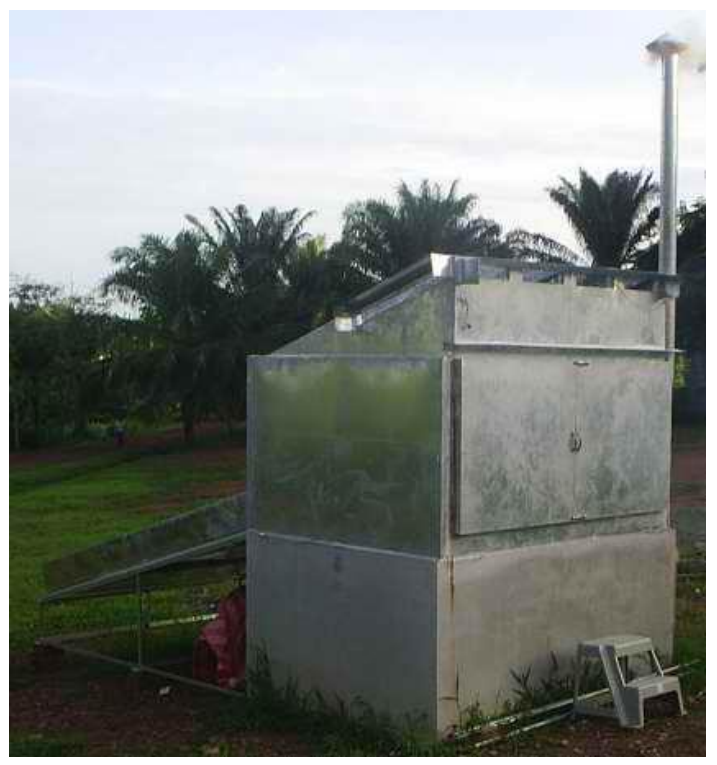

Gambar 4. Foto prototype pengering tenaga surya dengan bekup panas tenaga biomassa

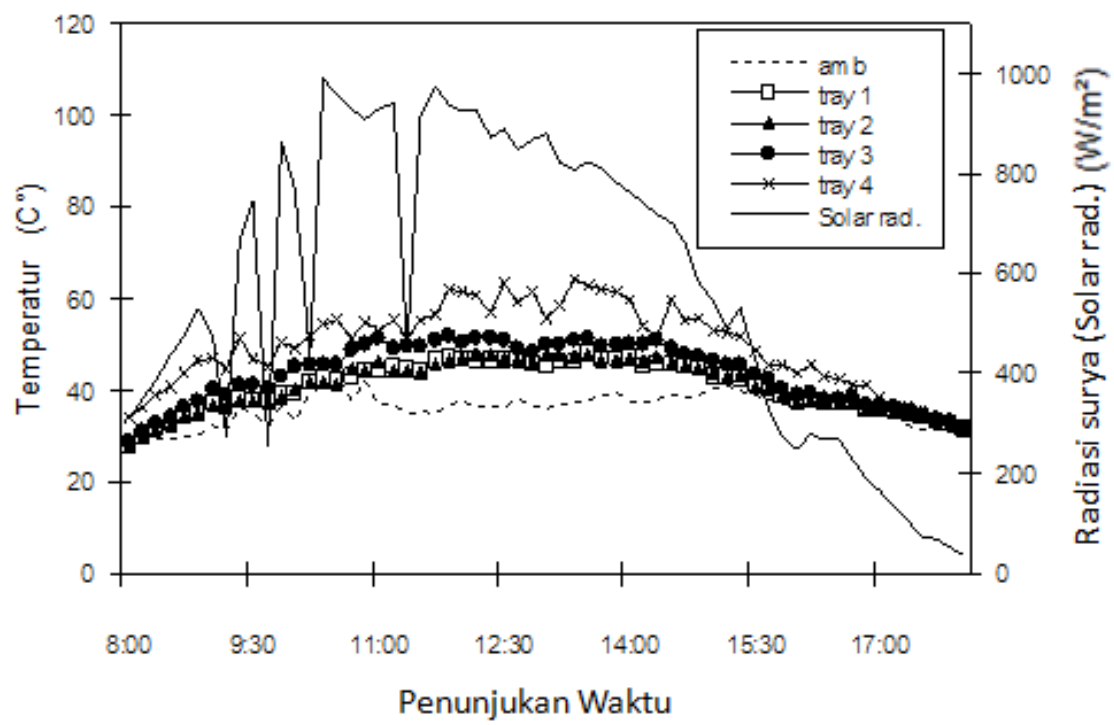

Gambar 5. Temperatur dalam rak/tray pengering dengan pengoperasian dengan tenaga surya

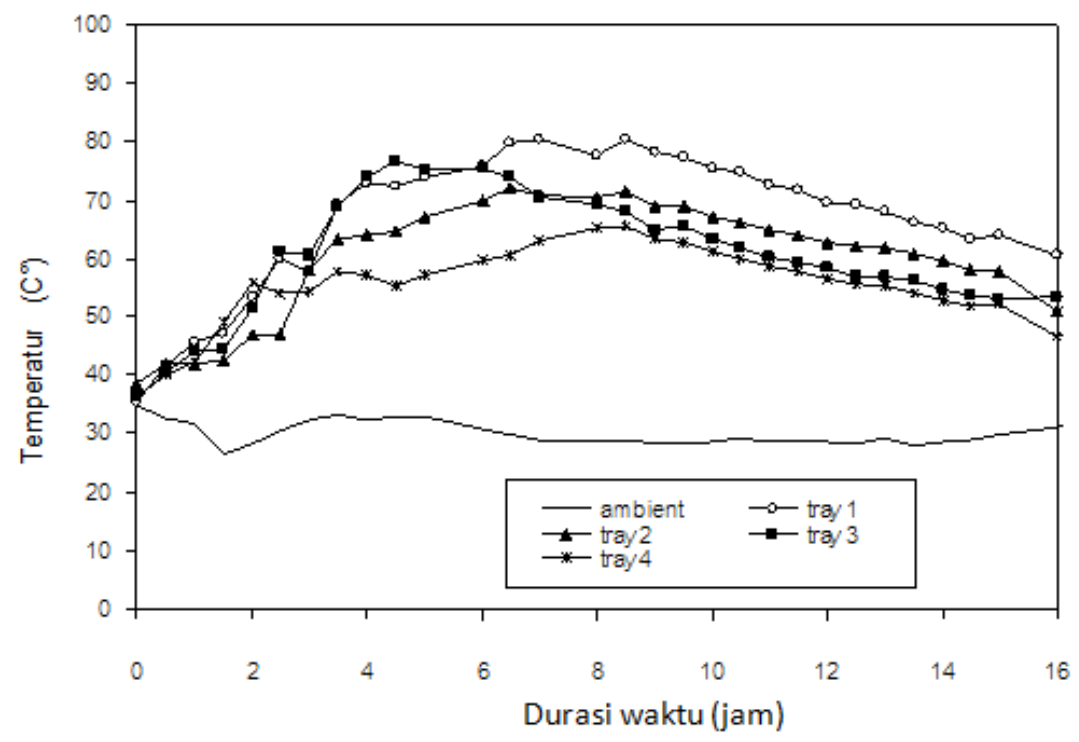

Gambar 6. Temperatur dalam rak/tray pengering dengan pengoperasian dengan biomassa 
Sistem bekap terhubung dengan sebuah cerobong asap yang merupakan tempat lewat asap dari pembakaran biomassa dilepaskan ke alam bebas. Sebelum masuk ke cerobong, asap yang masing mengandung panas akan melewati saluran/spasi kosong pada dinding rak yang didesain sedemikian menjadi "jaket" bagi rak. Dengan demikian pada saat pembakaran biomassa sebagai sumber energi pengeringan, panas dapat dimanfaatkan semaksimal mungkin dan produk dalam rak tidak terkontaminasi oleh asap. Diagram penampang melintang dari desain pengering seperti ditunjukkan pada Gambar 3.

Dalam keadaan kosong dan dengan menggunakan hanya energi surya didapati bahwa temperatur dalam kotak dan rak pengering bervariasi mulai dari sama dengan temperatur lingkungan hingga $65^{\circ} \mathrm{C}$ dan sangat bergantung pada tingkat radiasi matahari. Ketika radiasi diatas $800 \mathrm{~W} / \mathrm{m}^{2}$, temperatur dalam pengering mencapai $65^{\circ} \mathrm{C}$, dan hampir merata untuk setiap posisi dalam kotak/rak atau tray pengering. Salah satu hasil pengujian dalam kondisi kosong seperti ditunjukkan pada Gambar 5.

Evalausi penggunaan energi biomass dilakukan dengan memanfaatkan kayu api setengah kering sebagai bahan bakar. Dalam keadaan kosong, ditemukan bahwa dengan sekali isi penuh tungku dengan kayu bakar temperatur dalam dalam kotak/rak pengering mencapai $70^{\circ} \mathrm{C}$. Temperatur tersebut secara berangsur turun sampai $45^{\circ} \mathrm{C}$ dalam waktu 8 - 10 jam (Gambar 6).

Pada evaluasi pengering dengan menggunakan paduan radiasi surya dan biomass didapati bahwa pengering dapat dipakai secara kontiniue dimana pada siang hari supali panas dari radiasi matahari, dan kemudian malam hari diteruskan dengan suplai energi dari pembakaran biomassa. Demikian juga biomassa dapat dipakai pada siang hari ketika cuaca kurang baik.

Evaluasi dengan beban masing masing untuk pengeringan cabe rawit, kemiri, kacang kedelai, kacang hijau, dan kopi didapati bahwa pengeringan yang baik adalah dengan kontinyu, sehingga peran dari sistem bekup biomass sangat penting, lebih lagi ketika musim hujan atau ketika cuaca kurang baik. Kualitas sensorik (Balthazar et al., 2018; Duizer \& Walker, 2016) dari produk akhir setelah pengeringan juga menunjukan hasil yang baik.

\section{KESIMPULAN}

Pengering tenaga surya dengan sistem bekap panas tenaga biomass dapat dimanfaatkan untuk pengeringan berbagai hasil pertanian. Dengan memanfaatkan alat ini akan menghilangkan ketergantungan petani terhadap cuaca sebagaimana dihadapi bila mengeringkan produknya dengan metode tradisional penjemuran dialam terbuka. Dengan demikian Kualitas dan kuantitas produk para petani dapat meningkat. Desain, tipe dan ukuran pengering tenaga surya dapat ditentukan sedemikian sehingga sesuai dengan kebutuhan. Biaya pembuatannya relatif rendah dan dapat dibuat dengan teknologi sederhana oleh petani sendiri. Akan tetapi diperlukan dukungan dan perhatian dari berbagai pihak terutama pemerintah dan pengusaha untuk melakukan stimulasi pemanfaatan pengering tenaga surya tersebut.

\section{DAFTAR PUSTAKA}

Bahnasawy, A. ., \& Shenana, M. . (2004). A mathematical model of direct sun and solar drying of some fermented dairy products (Kishk). Journal of Food Engineering, 61(3), 309-319.
https://doi.org/10.1016/S0260-8774(03)00134-1

Balthazar, C. F., Santillo, A., Figliola, L., Silva, H. L. A., Esmerino, E. A., Freitas, M. Q., Albenzio, M. (2018). Sensory evaluation of a novel prebiotic sheep milk strawberry beverage. LWT, 98, 94-98. https://doi.org/10.1016/j.Iwt.2018.08.017

Duizer, L. M., \& Walker, S. B. (2016). The Application of Sensory Science to the Evaluation of Grain-Based Foods. In Reference Module in Food Science. Elsevier. https://doi.org/10.1016/b978-0-08-100596-5.00134-7

El-Sebaii, A. A., \& Shalaby, S. M. (2012). Solar drying of agricultural products: A review. Renewable and Sustainable Energy Reviews, 16(1), 37-43. https://doi.org/10.1016/j.rser.2011.07.134

Fudholi, A., Ridwan, A., Yendra, R., Pani Desvina, A., Hartono, H., Khan Bin Majahar Ali, M., Sopian, K. (2018). Solar Drying Technology in Indonesia: an Overview. International Journal of Power Electronics and Drive Systems (IJPEDS), 9(4), 1804. https://doi.org/10.11591/ijpeds.v9.i4.pp1804-1813

Kabeel, A. E., \& Abdelgaied, M. (2016). Performance of novel solar dryer. Process Safety and Environmental Protection (Vol. https://doi.org/10.1016/j.psep.2016.03.009

Kumar, M., Sansaniwal, S. K., \& Khatak, P. (2016). Progress in solar dryers for drying various commodities. Renewable and Sustainable Energy Reviews, 55, 346-360. https://doi.org/10.1016/j.rser.2015.10.158

Morad, M. M., El-Shazly, M. A., Wasfy, K. I., \& ElMaghawry, H. A. M. (2017). Thermal analysis and performance evaluation of a solar tunnel greenhouse dryer for drying peppermint plants. Renewable Energy, 101 , https://doi.org/10.1016/j.renene.2016.09.042 992-1004.

Rabha, D. K., Muthukumar, P., \& Somayaji, C. (2017). Experimental investigation of thin layer drying kinetics of ghost chilli pepper (Capsicum Chinense Jacq.) dried in a forced convection solar tunnel dryer. Renewable Energy, 105, 583-589. https://doi.org/10.1016/j.renene.2016.12.091

Sharma, V. K., Sharma, S., \& Garg, H. P. (1991). Mathematical modelling and experimental evaluation of a natural convection type solar cabinet dryer. Energy Conversion and Management, 31(1), 65-73. https://doi.org/10.1016/0196-8904(91)90106-S

Simate. (2003). Optimization of mixed-mode and indirectmode natural convection solar dryers. Fuel and Energy Abstracts, 44(4), 236. https://doi.org/10.1016/S01406701(03)83005-9

Tarigan, E., \& Tekasakul, P. (2007). A small scale solar agricultural dryer with biomass burner and heat storage back-up heater. In ISES Solar World Congress 2007, ISES 2007 (Vol. 3).

Tarigan, Elieser. (2018). Mathematical Modeling and Simulation of a Solar Agricultural Dryer with Back-Up Biomass Burner and Thermal Storage. Case Studies in Thermal https://doi.org/10.1016/j.csite.2018.04.012

Wu, J., Zhang, X., Shen, J., Wu, Y., Connelly, K., \& Yang, T. (2017). A review of thermal absorbers and their integration methods for the combined solar photovoltaic / thermal ( PV / T ) modules. Renewable and Sustainable Energy Reviews, 75(November 2016), 839-854. https://doi.org/10.1016/j.rser.2016.11.063

Yassen, T. A., \& Al-Kayiem, H. H. (2016). Experimental investigation and evaluation of hybrid solar/thermal dryer combined with supplementary recovery dryer. Solar Energy, 134, 284-293. 
TEKNOTAN, Vol. 14, No. 1, Agustus 2020

https://doi.org/10.1016/j.solener.2016.05.011 